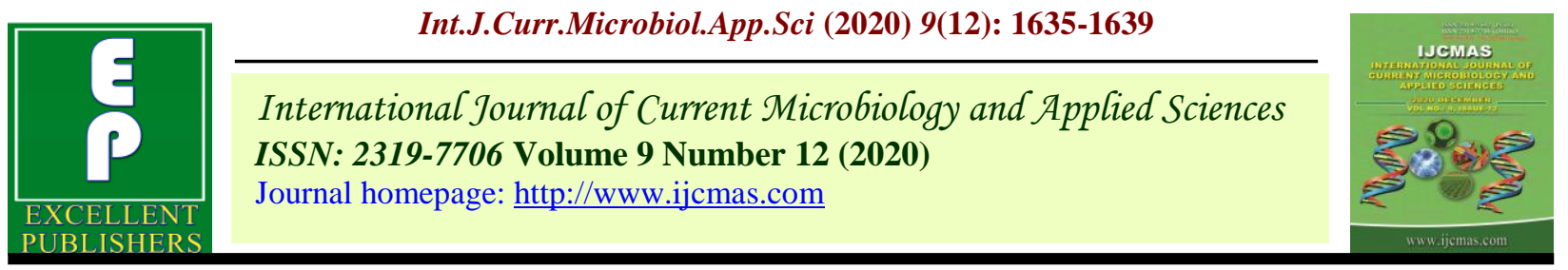

Original Research Article

https://doi.org/10.20546/ijcmas.2020.912.194

\title{
An Economic Analysis of Production of Pearl Millet (Pennisetum glaucum) in Sikar District of Rajasthan, India
}

\author{
Sundar Lal ${ }^{*}$, Sanjay Kumar and Vikash Singh \\ Department of Agricultural Economics, Sam Higginbottom University of Agriculture, \\ Technology \& Sciences, Prayagraj, (U.P.) India \\ *Corresponding author
}

\begin{abstract}
A B S T R A C T
\section{Keywords}

Pearl millet,

Production, Sikar,

Cost and return

Article Info

Accepted:

12 November 2020

Available Online:

10 December 2020

The present study entitled 'An economic analysis of production of pearl millet in sikar district of Rajasthan' was conducted in the year 2019-20 with a sample of 120 respondents. The results indicated that the total cost of cultivation of Pearl millet for small, medium and large size farms were (Rs.27020.70/ha, Rs 26672.20 Rs/ha and 25390.50/ha) respectively. The gross returns obtained per hectare by large size and medium size farms were high (Rs.38000/ha) as compare to small size farms (Rs.36000/ha) respectively, and the net returns per hectare obtained by large size farms were high (Rs.12609.50/ha) as compared to medium and small size farms (Rs.11327.80/ha and Rs.8979.30/ha) respectively. Input-output ratio per hectare was highest in large size farms $(1: 1.50)$ compare to medium and small size farms (1:1.42 and 1:1.33).
\end{abstract}

\section{Introduction}

India is the largest producer of pearl millet, both in terms of area (9.1 million hectares) and production (7.3 million tons), with an average productivity of $780 \mathrm{~kg} / \mathrm{ha}$ during the last 5 years (WOAB, 2010). As compared to the early in 1980, the pearl millet area in India has declined by 26 per cent during the last five years, but production has increased by 19 per cent owing to 44 per cent increase in productivity. Pearl millet cultivation is done mainly during Kharif (rainy) season across the country. It is also grown to a lesser extent during Rabi (post rainy) season in Andhra Pradesh, Karnataka, Tamil Nadu and
Pondicherry. Summer pearl millet cultivation varies from state to state with varying rainfall and soil type. The marketing component is important to ensure remunerative prices to the farmers ' which will eventually work as an incentive for them to bring more area under cereals. Marketing can also help in inducing an element of incentive to fanner through participation in processing and distribution of Pearl millet through direct marketing, farmers market or cooperative marketing to get higher share in the consumer's price. Marketing innovations like group marketing will help in improving the bargaining powers of small and marginal farmers. 
Pearl millet is a warm weather crop and grows best at 20 to $28^{\circ} \mathrm{C}$. Pearl millet is more tolerant to higher temperatures than probably any other cultivated cereal. The best temperature for the germination of pearl millet seed is 23 to $32^{\circ} \mathrm{C}$. Pearl millet seed does not germinate and grow well under cool soil conditions.

The optimum rainfall requirement of pearl millet ranges $35-50 \mathrm{~cm}$. But, pearl millet can be grown in areas, which receive less than 35 $\mathrm{cm}$ of annual rainfall. Prolonged spells of warm, rainless weather may be detrimental and may lead to reduced crop yields. Pearl millet is one of the toughest; drought tolerant crop and it maintain its popularity in the regions where the weather is very unpredictable.

The Sikar district is a major pearl millet growing district of Rajasthan. This district produced 243895 tonnes of pearl millet from 266367 hectares area with productivity of 916 $\mathrm{kg} / \mathrm{ha}$ during the year 2018-19.

The study of an economic analysis of production of pearl millet in sikar district of Rajasthan and data was collected in the year 2019-20.

\section{Materials and Methods}

The present study was conducted in Sikar District of Rajasthan. The Sikar district contains 6 blocks viz Fatehpur, Danta Ramgarh, Lachhmangarh, Sri Madhopur, Sikar, Neem Ka Thana. Among all these blocks, Sri Madhopur block was purposively selected due to largest area and production under Pearl millet crop. Further, out of Sri Madhopur block seven villages were selected. For selection of respondents were categorized into three groups on the basis of area under Pearl millet cultivation in all the selected villages.
Small size farm group -having area of cultivation less than 1 ha

Medium size farm group- having area of cultivation of 1-2 ha

Large size farm group- having area of cultivation more than 2 ha

$10 \%$ farms household were selected in all the three size farm groups in each selected village. Altogether total respondents were 120 viz., 57 small respondents, 42 medium respondents and 21 large respondents respectively.

The interview method used for data collection. Interview schedule was divided into major parts. First section included profile of respondents and second section was I question related to economic analysis of production of pearl millet.

\section{Results and Discussion}

Table 1 revealed that among different size of farms during bearing period, total cost incurred by the small size farms were high (Rs.27020.70/ha) as compared to medium and large size farms (Rs.26672.20/ha and Rs.25390.50/ha). Sample average for total cost was Rs.26361.13/ha in different size of farms group.

The cost of human labor, fertilizers, and machinery labor were the items of cost with major share in the variable costs, because most of the operations like harvesting, and weeding were human labor intensive operations.

The distribution of pattern of operational cost under various inputs revealed that cost of human labor was the highest in the small size farms (Rs.3600./ha), compared to medium size and large size farms (Rs.3300/ha) respectively. 
Table.1 Cost of Cultivation of Pearl millet crop per hectare in different Size of Farms Group, during gestation period. Number of Respondents $=120 \mathrm{~S} \mathrm{M} \mathrm{L}=57+42+21=120$ (Value in

Rupees/hectare)

\begin{tabular}{|c|c|c|c|c|c|}
\hline S.No & Different farm operation & \multicolumn{2}{|c|}{ Size of farm group } & Sample \\
& & Small & Medium & Large & average \\
\hline $\mathbf{1}$ & Hired human labour & 1200 & 1800 & 1500 & $\mathbf{1 5 0 0 . 0 0}$ \\
\hline $\mathbf{2}$ & Bullock labour charges & 2500 & 2000 & 2000 & $\mathbf{2 1 6 6 . 6 7}$ \\
\hline $\mathbf{3}$ & Machinery labour charges & 2400 & 2400 & 2400 & $\mathbf{2 4 0 0 . 0 0}$ \\
\hline $\mathbf{4}$ & Cost of seedling & 550 & 500 & 400 & $\mathbf{4 8 3 . 3 3}$ \\
\hline $\mathbf{5}$ & Cost of farm yard manure & 1000 & 800 & - & $\mathbf{6 0 0 . 0 0}$ \\
\hline $\mathbf{6}$ & Cost of chemical fertilizer & 1375 & 1375 & 1375 & $\mathbf{1 3 7 5 . 0 0}$ \\
\hline $\mathbf{7}$ & Cost of irrigation charges & - & - & - & - \\
\hline $\mathbf{8}$ & Cost of plant protection charges & - & 300 & 300 & $\mathbf{2 0 0}$ \\
\hline $\mathbf{9}$ & Miscellaneous charges & 300 & 300 & 300 & $\mathbf{3 0 0}$ \\
\hline $\mathbf{1 0}$ & Interest on working capital @6-8\% & 600.00 & 602.00 & 598.00 & $\mathbf{6 0 0 . 0 0}$ \\
\hline $\mathbf{1 1}$ & Deprecation on fixed resources 10\% & 760 & 545 & 465 & $\mathbf{5 9 0}$ \\
\hline $\mathbf{1 2}$ & Land revenue paid to government & 40 & 40 & 40 & $\mathbf{4 0}$ \\
\hline $\mathbf{1 3}$ & Interest on fixed capital @ 10\% & 695.70 & 710.20 & 712.5 & $\mathbf{7 0 6 . 1 3}$ \\
\hline $\mathbf{1 4}$ & Rental value of own land & 12000 & 12000 & 12000 & $\mathbf{1 2 0 0 0}$ \\
\hline $\mathbf{1 5}$ & Imputed value of family labor charges & 3600 & 3300 & 3300 & $\mathbf{3 4 0 0}$ \\
\hline & Total cost of cultivation & 27020.70 & 26672.20 & 25390.50 & $\mathbf{2 6 3 6 1 . 1 3}$ \\
\hline
\end{tabular}

Table. 2 Cost concept in pearl millet crop per hectare in different size of farm group Number of Respondents $=120$ S M L $=57+42+21=120$ (Value in rupees)

\begin{tabular}{|c|c|c|c|c|c|}
\hline S.No & Different farm & \multicolumn{3}{|c|}{ Size of farm group } & Sample average \\
\cline { 3 - 6 } & operation & Small & Medium & Large & \\
\hline $\mathbf{1}$ & Cost $\mathrm{A}_{1}$ & 10725.00 & 10662.00 & 9378.00 & $\mathbf{1 0 2 5 5 . 0 0}$ \\
\hline $\mathbf{2}$ & Cost $\mathrm{A}_{2}$ & 10725.00 & 10662.00 & 9378.00 & $\mathbf{1 0 2 5 5 . 0 0}$ \\
\hline $\mathbf{3}$ & Cost $\mathrm{B}$ & 23420.70 & 23372.20 & 22090.50 & $\mathbf{2 2 9 6 1 . 1 3}$ \\
\hline $\mathbf{4}$ & Cost $\mathrm{C}$ & 27020.70 & 26672.20 & 25390.50 & $\mathbf{2 6 3 6 1 . 1 3}$ \\
\hline
\end{tabular}

Table.3 Cost and return in pearl millet crop per hectare in different size of farm group Number of Respondents=120 S M L =57+42+21=120 (Value in rupees/qtl)

\begin{tabular}{|c|c|c|c|c|c|}
\hline \multirow{2}{*}{ S.No } & Different farm operation & \multicolumn{3}{|c|}{ Size of farm group } & Sample \\
& & Small & Medium & Large & average \\
\hline $\mathbf{1}$ & Total cost of cultivation & 27020.70 & 26672.20 & 25390.50 & $\mathbf{2 6 3 6 1 . 1 3}$ \\
\hline $\mathbf{2}$ & Yield in quintal per hactare & 18 & 19 & 19 & $\mathbf{1 8 . 6 6}$ \\
\hline $\mathbf{3}$ & Gross return per hectare in rupees & 36000 & 38000 & 38000 & $\mathbf{3 7 3 3 3 . 3 3}$ \\
\hline $\mathbf{4}$ & Net return per hectare & 8979.30 & 11327.80 & 12609.50 & $\mathbf{1 0 9 7 2 . 2 0}$ \\
\hline $\mathbf{5}$ & Cost of production per quintal & 1501.15 & 1403.80 & 1336.34 & $\mathbf{1 4 1 3 . 7 6}$ \\
\hline $\mathbf{6}$ & Price per quintal & 2000 & 2000 & 2000 & $\mathbf{2 0 0 0}$ \\
\hline $\mathbf{7}$ & Input and output ratio & $1: 1.33$ & $1: 1.42$ & $1: 1.50$ & $\mathbf{1 : 1 . 4 2}$ \\
\hline
\end{tabular}


As Pearl millet would respond well with chemical fertilizer so the cost of farm yard manure used was ranged from Rs.1000 (small size farms) to Rs.800 (medium size farms).Whereas the expenditure on fertilizers was same in all size of farm group (Rs.1375/ha). Sample average for depreciation on fixed resources was Rs.590.00 interest on working capital Rs.600.00, interest on fixed capital was Rs.706.13 Land revenue paid to government was Rs 40 in different size of farms group.

Table 2 reveals that Cost Concepts on different size of farms group per hectare. Cost A1 was highest in small size farms (Rs.10725/ha) followed by medium size farms (Rs.10662/ha) and lowest in large size farms (Rs.9378/ha) respectively. Cost A2 in small, medium and large size of farms groups was Rs.10725/ha, Rs.10662/ha and Rs.9378/ha respectively. Cost B was highest in small size farms (Rs.23420.70/ha) as compared to medium size farms (Rs.23372.20/ha) and lowest in large of farms (Rs.22090.50/ha) respectively. Cost C was highest in small size farms (Rs.27020.70/ha) and lowest in large size farms (Rs.25390.50/ha). Sample average for Cost A1, Cost A2, Cost B and Cost C was Rs.10255/ha, Rs.10255/ha, Rs.22961.13/ha and Rs.26361.13/ha in different size of farms group.

Table 3 reveals that Costs and Returns in Pearl millet cultivation in different size of farms group. Among different size of farms groups, the total cost of cultivation incurred by the small farms were high (Rs.27020.70/ha) as compared to medium (Rs.26672.20/ha) and large farms (Rs.25390.50/ha). Sample average for total cost of cultivation was Rs.26361.13/ha in different size of farms group. The gross returns obtained per hectare by large size and medium size farms were high (Rs.38000/ha) as compare to small size farms (Rs.36000/ha) respectively. The net returns per hectare obtained by large size farms were high (Rs.12609.50/ha) as compared to medium and small size farms (Rs.11327.80/ha and Rs.8979.30/ha) respectively.

The average yield of Pearl millet in different size of farms group was $18.66 \mathrm{qtl} / \mathrm{ha}$. The yield was highest in case of large size farms 19qtl/ha as compared to medium 19qtl/ha and small size farms 18qtl/ha respectively. Average cost of production per quintal was Rs. 1413.76/qtl. Minimum support price per quintal was Rs.2000/qtl.

In conclusion the study shows that the production of Pearl millet in Sikar is to analyze, economics of Pearl millet production. The results revealing that the economics of Pearl millet production is more profitable in large farms as compared to medium size farms and small size farms.

\section{References}

Agarwal, PK. and Singh, O.P. (2015), An economic analysis of soybean cultivation in Ratlam district of Madhya Pradesh, India. Indian Journal of Agricultural Research, 49(4): 308-314.

Asmatoddin M. Jawale S.V. and Perke D.S. 2009, "Economic analysis of pulses on medium farms in Marathwada region of Maharashtra" Agriculture update; 4: 3/4:262-265.4.

Changule, R.B. and Gaikwad, GP. (2013), "Marketed surplus and price spread in different channels of maize marketing". International journal of commerce and business management, 6(1).76-79

Deshmukh, Pawar, D.S., Landge, B.R., Yeware, V.V. and P.P. (2010) "Marketed surplus and price spread in different channels of Pearl millet marketing". International journal of 
commerce and businws management; 3(1):41-44

Dinesh., 2011, Production and value addition to groundnut in Chitradurga district of Kamataka, An economic analysis. M.Sc. (Agri). Thesis, Univ. Agric. sci., Dharwad, Kamataka (India).

Kumara, B. R., Hosamani, S. B., Mamle desai, N. R., Megeri, S. N. and Hosamani, M. H., 2012, Costs and returns of major cropping systems in northern transition zone of Karnataka. Karnataka J. Agric. Sci., 25 (2): (208211).

Latha, K. B., 2003, A Critical analysis of Adoption level, Economic performance and Marketing channels of coconut growers in central dry zone of Kamataka, M.Sc. (Agri.) Thesis (Unpub.), University of Agricultural Sciences, Bangalore.

Lahoti, S. R., Chole, R. R. AND Rathi, N. R., 2010. Constraints in Adoption of Sugarcane Production Technology. Agricultural Science Digest. 30 (4):270272.
Marimuthu. P. and Rathakrishnan., 2001, Problems faced by banana growers, 12(3): 3235-3236.

Meena, D. C., 2009, an economic analysis of production and marketing of rapeseed mustard in selected districts of Rajasthan. M. Sc. (Agri). Thesis. Univ. Agric. Sci., Dharwad, Kamataka (India). Naik, D., Singh, D. N. and Mohanty, B. C., 2006, Cost and return of groundnut crop in Hinjilicutblock of Orissa. Indian $\mathbf{J}$. Agric. Mktg., 20 (3): 54-56.

Narayan, P. And Kumar, S. (2015). Constraints of growth in area production and productivity of pulses in India, An analytical approach to major pulses,49(2): 114-124.

Prusty, S.R. and Tripathy, S. (2017). Marketing of pulses in Jagatsinghpur district of Odisha. 13(1); 159-164.

Reddy, S. Y., and Reddy, G. P., 2005, "Production and marketing constraints of sunflower cultivation in Andhra Pradesh". Indian J. Agric. Mktg., 19 (3) : 20-27.

\section{How to cite this article:}

Sundar Lal, Sanjay Kumar and Vikash Singh. 2020. An Economic Analysis of Production of Pearl Millet (Pennisetum glaucum) in Sikar District of Rajasthan, India. Int.J.Curr.Microbiol.App.Sci. 9(12): 1635-1639. doi: https://doi.org/10.20546/ijcmas.2020.912.194 